\title{
ORGANIZACJA PRZESTRZENI WŁADZY PRZEZ BORYSA JELCYNA I WŁADIMIRA PUTINA - PODOBIEŃSTWA I RÓŻNICE
}

Stworzony na podstawie rosyjskiej konstytucji system instytucji władzy, jak również odpowiadające mu mechanizmy podejmowania decyzji, zorientowane były bardziej na scentralizowanie pełni władzy i przestrzeni politycznej w rękach prezydenta niż na tworzenie systemu współodpowiedzialności za państwo. Silna władza prezydencka, obdarzona ogromnym potencjałem pełnomocnictw, nie była jednak przeznaczona do zadań modernizacji lub formowania swego rodzaju „dyktatury rozwoju”. Celem władzy było stworzenie polityczno-prawnych warunków do tego, żeby postsowieckie elity mogły zachować swoją dominującą pozycję w społeczeństwie. W tym kontekście głównym zadaniem systemu był ponowny podział zasobów, a władzy prezydenckiej została wyznaczona rola arbitra decydującego o ich redystrybucji i sposobie rozwiązywania konfliktów. W takim ujęciu mechanizmów politycznych tkwiło jednak zagrożenie: jeśli władza lekceważyła swoje zadania lub nie była zdolna zdolna wypełniać roli arbitra, system stopniowo przestawał funkcjonować we właściwy sposób ${ }^{1}$.

Niniejsza analiza ma na celu pokazanie w jaki sposób ,,przestrzeń władzy politycznej” była/jest organizowana w czasach Borysa Jelcyna i Władimira Putina ${ }^{2}$. Jakie występują tu podobieństwa i różnice, jakie czynniki spowodowały, że reżim Putina jest sprawniejszy niż system stworzony przez jego poprzednika. „Przestrzeń władzy politycznej" jest tu rozumiana jako swoisty układ mechanizmów gry politycznej i wzajemnych zależności w trójkącie: prezydent - elity władzy - grupy interesów.

\footnotetext{
1 А. Рябов, Проблема авторитаризма и демократии в современной России в контексте задачи консолидации власти, „Briefing” 2000, nr 11, s. 3-4.

2 Dimitrij Miedwiediew był jedynie prezydentem „technicznym”, a kierownictwo państwa skupione zostało w rękach ówczesnego premiera - Władimira Putina.
} 


\section{Organizacja przestrzeni władzy politycznej w modelu Borysa Jelcyna}

26 grudnia 1991 roku Borys Jelcyn oficjalnie stał się prezydentem nowego, suwerennego państwa - Federacji Rosyjskiej. Mógł podejmować decyzje sam, tj. bez żadnej kontroli i presji centrum. Obdarzony, przyznanymi mu przez parlament, specjalnymi pełnomocnictwami stawał się najważniejszym kreatorem polityki. Cała odpowiedzialność za kierunek reform i stan państwa spadała na niego. To on miał prowadzić Rosję ku przemianom gospodarczym i demokracji. Zlekceważył jednak, (lub nie docenił), skali problemów i wyzwań, które stanęły przed Rosją i przed nim samym. Należało m.in. ustabilizować gospodarkę, stworzyć wolny rynek, zdemokratyzować instytucje państwa i system władzy, na nowo ułożyć relacje wewnątrz obszaru postradzieckiego i szerzej - w polityce międzynarodowej. Tak naprawdę problemy były znacznie większe niż w byłych krajach tzw. demokracji ludowej. W Rosji chodziło nie tylko o reformy rynkowe i transformację ustrojową, ale praktycznie o budowę nowego państwa. Jelcyn nie był przygotowany do przeprowadzenia tak fundamentalnych zmian. Wydawało mu się, że samo mówienie o demokracji i wolnym rynku do pewnego stopnia zastąpi konkretne reformy. Gawriłł Popow pisał, że stosunek Jelcyna do reform był bardzo podobny do stosunku Stalina do NEP-u, kolektywizacji, industrializacji, religii, patriotyzmu, antysemityzmu itd. wszystko co umacniało władzę wydawało się pozytywne i niezbędne. Reformy były prezydentowi potrzebne, ponieważ sądził, że bez nich jego władza osłabnie ${ }^{3}$.

Jelcyn nie zdecydował się na radykalne działania mogące w sposób rzeczywisty zreformować kraj: dekomunizację, rozwiązanie parlamentu i przeprowadzenie wyborów w warunkach pełnej suwerenności kraju, czy szybką, radykalną zmianę prawa konstytucyjnego. W konsekwencji Rosja po 1991 r. była budowana na fundamencie ZSRR przy czym kolejne problemy kraju rozwiązywano nie przez intensyfikację reform a przez coraz silniejszą adaptację do nowych realiów rozwiązań, ludzi i koncepcji z czasów komunistycznych czy nawet carskich. Było to poniekąd naturalne. W swojej historii Rosja przeżywała wiele prób modernizacji, które za każdym razem kończyły się krokiem w tył - tryumfem reakcji. Co ważniejsze, opinia publiczna zawsze stawała po stronie „reakcjonistów”, ciesząc się z porażki reformatorów ${ }^{4}$. Lilia Szewcowa pisała, że patrząc na ewolucję rosyjskiej cywilizacji poprzez formułę Arnolda Toynbeego - ,wyzwania i odpowiedzi” - można dostrzec, że kiedy państwo zbliżało się do kryzysu, rosyjskie elity zamiast zaoferować nowe zasady organizacji społeczeństwa oferowały jedynie nowe formy wdrażania starych zasad. Rzecz szła o utrzymanie triady - personalnej władzy, zespolenia władzy i własności oraz zachowania sfery wpływów geopolitycznych. Wszystkie próby rosyjskiej

3 Г. Попов, Будет ли у России второе тысячелетие, Москва 1998, s. 189.

4 И. Бунин, Драма модернизации и болото реакции, http://www.politcom.ru/2003/pvz305.php (data dostępu: 07.09.2006 r.). 
reformizmu okazywały się pomysłami na zachowanie tych trzech elementów. Rosja tworzyła $\mathrm{w}$ ten sposób unikalną cywilizację, która była w stanie wejść w nowoczesność poprzez maksymalne wykorzystanie czynników prowadzących z reguły do upadku innych cywilizacji: centralizację, militaryzację i eksploatację własnych zasobów ludzkich5. Przeobrażenia w Rosji dokonywały się więc według pewnego schematu, którego celem była odbudowa autorytetu władzy, a także jej centralnego i dominującego miejsca w państwie. W dużym stopniu wynikało to z przesłanek społeczno-kulturowych tj. społecznej potrzeby, by odtworzyć historyczny model silnej władzy politycznej. Wiele elementów systemu politycznego Rosji było tym samym prostą kontynuacją tradycji i rozwiązań z poprzednich epok, przy czym ich szeroka adaptacja wpływała stabilizująco na państwo i władzę. Wyłaniająca się w procesie transformacji kultura polityczna również okazała się w dużym stopniu funkcjonalna w stosunku do kultury politycznej w poprzednim systemie. Było to zaskakujące, ponieważ wydawało się, że procesy transformacji przełomu lat $80 . / 90$. bezpowrotnie rozbiły dawne struktury społeczne i radziecką mentalność społeczeństwa. Okazało się jednak, iż czynnik kulturowy tkwił dużo głębiej niż szczep komunistycznego siewu. Jego powtórnej adaptacji służyło załamanie sowieckiej ideologii i poszukiwanie nowego ładu. Tu najłatwiej było zaś zwrócić się do bogatej tradycji historycznej, a tym samym w kierunku ograniczenia wolności na rzecz jakieś formy autokracji.

Przeobrażenia w Rosji po 1991 roku dokonywały się więc według utartego schematu, którego celem była odbudowa autorytetu władzy, a także jej centralnego i dominującego miejsca w państwie. Służyć temu miały dwa podstawowe mechanizmy - ,powściągania” i „,wertykału”. Pierwszy z nich polegał na tolerowaniu na Kremlu kilku równocześnie działających i wzajemnie zwalczających się obozów, które obustronnie hamowały swoje wpływy i możliwości zawłaszczenia władzy. Mechanizm ten, stworzony w istocie w czasach sowieckich, był stosowany także w odniesieniu do pojedynczych osób, których pozycja ewentualnie mogła okazać się zbyt silna, czy regionalnych liderów. Swoich ,aniołów stróżów” w postaci wicepremierów mieli w zasadzie wszyscy szefowie rządów. Mechanizm „wertykału” wywodził się jeszcze z XXVIII zjazdu KPZR, kiedy to pojawiła się koncepcja wzmocnienia władzy centrum nad prowincjami ${ }^{6}$. Wtedy Jelcyn krytykował ją jako niedemokratyczną, wkrótce jednak (jesienią 1991 r.), zaczął aktywnie wcielać w życie jej założenia, obsadzając struktury państwa ludźmi lojalnymi wobec Kremla. „Wertykał” był koncepcją układu władzy ciągnącego się od samej góry, tj. od prezydenta, do dołu. Naturalną analogią może tu być struktura wojskowa, gdzie każdy podwładny, otrzymując rozkaz, musi wykazać się lojalnością przy jego wykonaniu.

Polityczna pozycja Borysa Jelcyna, chociaż uwarunkowana czynnikami osobowościowymi i normatywnymi (oba ulegały zresztą zmianie), w głównej mierze była

5 Л. Шевцова, Россия: логика упадка, „Новая газета” 12 сентября 2011.

6 Л. Шевцова, Режим Бориса Ельцина, Моск. Центр Карнеги, Москва, РОССпЭН, 1999, s. 54. 
jednak pochodną systemu nieformalnych zależności w łonie nomenklatury, służb, grup interesu, a z czasem też „oligarchów”. Powiązania te powodowały, że prezydent mógł poruszać się jedynie w stosunkowo wąskim „korytarzu możliwości”. Nie mógł więc wprowadzać reform, które naruszałyby interesy formalnych i nieformalnych uczestników gry politycznej czy prowadzić w pełni samodzielnej polityki wewnętrznej i zagranicznej. To, jak wyglądały rosyjskie reformy wynikało w dużej mierze z możliwości, które czasem udawało mu się powiększać - po puczu Gienadija Janajewa (sierpień 1991 r.) doprowadził do rozwiązania ZSRR i przeforsowania pakietu reform rynkowych Jegora Gajdara, po rozwiązaniu parlamentu we wrześniu 1993 roku wprowadził reformę konstytucyjną. W obu wypadkach nie posunął się jednak na tyle daleko, by naruszyć interesy tych, z którymi musiał się liczyć. Wydaje się to logiczne. Naczelnym zadaniem władzy politycznej w Rosji (bez znaczenia czy był to prezydent czy parlament) nie była głębsza modernizacja państwa, ale stworzenie polityczno-prawnych warunków do tego, żeby postsowieckie elity, przeobraziwszy się, mogły zachować swoją dominującą pozycję. Poparcie elit i grup interesu warunkowało przy tym zwycięstwo w konflikcie między egzekutywą i legislatywą.

Jelcyn bardzo długo budował swoją pozycję jako najwyższego arbitra umiejętnie manipulującego interesami poszczególnych „klanów” i „koterii”. W 1997 roku jego rola ulega jednak zmianie. Miało to bezpośredni związek z szeregiem kompromisów zawartych w początkach 1996 roku. Szukając poparcia przed zbliżającą się batalią o reelekcję, zaczął zakulisowe gry z siłami politycznymi, opozycją czy wielkim biznesem. W zamian za pomoc, przedstawiciele regionalnych i finansowych elit uzyskali szerokie koncesje polityczne i gospodarcze. Co więcej, poczuli, że mogą być niezależni od prezydenta ${ }^{7}$ W ten sposób rozpoczął się proces stopniowego poszerzania autonomii politycznej i gospodarczej przez regiony, rozmaite grupy interesu, i oligarchię finansową. Rosją zaczęły wstrząsać wojny „klanów” toczone przez „oligarchów”. W tym wypadku ostatecznym sędzią i rozjemcą pozostawała jednak władza polityczna, do której zawsze można się było odwołać. Jej rozstrzygnięcia mogły być arbitralne i niesprawiedliwe, często zależały od humorów Borysa Jelcyna czy interesów jego najbliższych, ale istniała możliwość arbitrażu. Wydaje się, że obie strony, tj. prezydent i „oligarchowie”, z rozmysłem tolerowały istnienie swoistego status quo pomiędzy państwem i biznesem - dopuszczającego funkcjonowanie ,paralelnej” gospodarki w zamian za akceptację lidera - ponieważ sądziły, że mogą się wzajemnie kontrolować i równoważyć. Układ ten wydawał się zresztą optymalny: oligarchowie wspierali reżim, reżim zaś pozwalał im kontrolować zasoby państwa i przenosić je w „szarą sferę”. Samo przechodzenie elit w „cień” wydawało się przy tym istotne przynajmniej z dwóch powodów: ekonomicznego i politycznego - które można jednakoż sprowadzić do wspólnego mianownika. Funkcjonujące w przestrzeni publicznej elity zmuszone były grać według 
jej prawideł, to znaczy stale legitymizować siebie w oczach państwa i społeczeństwa $^{8}$. Pozbywszy się tej niedogodności, tj. konieczności funkcjonowania w owej przestrzeni publicznej, mogły bardziej swobodnie realizować swoje korporacyjne interesy, zwłaszcza w okresie, kiedy państwo nie przeciwstawiało się półlegalnym czy nielegalnym praktykom. Poszczególne „klany” zawzięcie walczyły o swoje partykularne interesy polityczne, nie oglądając się na los państwa i tolerując prezydenta jedynie jako gwaranta swoich wpływów. Trudno przy tym mówić o jakimś zabarwieniu ideologicznym poszczególnych „klanów”. Zarówno „reformatorzy” - „klan” Czubajs-Fiłatow, „konserwatyści” - „klan” Korżakow-Borsukow-Soskowiec, jak i „centryści” - „klan” Łużkowa, mieli podobne cele strategiczne, które polegały na prostym korzystaniu z zasobów i dóbr państwa9. Konsekwencją tego stanu było załamywanie się systemu wertykalnej odpowiedzialności i kontroli. Thomas Grechem pisał, że „klany” politycznie zgadzały się na pozostawienie instytucji i procedur demokratycznych, przede wszystkim wolnych wyborów, które umacniały ich władzę i wpływy. David Hoffman, w pracy o rosyjskich oligarchach zwracał uwagę, że po wyborach 1996 roku zaczęli oni stanowić jedność z Kremlem, pozostając w całkowitej zależności od siebie ${ }^{10}$. W latach 90 . w ich interesie leżało zachowanie procedury i retoryki demokratycznej, nie było jednak gwarancji, że w razie realnej groźby porażki, polityczne decyzje nie miałyby zgoła odmiennego charakteru. Pogłębiał się też wrośnięty w strukturę władzy konflikt między koniecznością demokratycznego wyboru lidera a administracyjno-autorytarnym sposobem sprawowania władzy, między autorytarną tradycją a koniecznością demokratycznej legitymizacji. Rozwiązaniem tego problemu było stopniowe sprowadzanie rosyjskiej demokracji do samej procedury głosowania, zresztą w coraz większym stopniu quasi-wolnej. W ten sposób władza zaczęła świadomie ograniczać a w końcu realnie tracić zdolność komunikowania się z aktywną częścią Rosjan, postrzeganych coraz częściej jako przeciwników abstrakcyjnego ,interesu zbiorowego".

Paradoksalnie okazało się więc, że sukces wyborczy Jelcyna w 1996 r. był zarazem początkiem degradacji jego roli politycznej ${ }^{11}$. Rosyjskie „klany” i powiązane z nimi lobby - potężne koła finansowe i przemysłowe - potrafiły już same koordynować swoje interesy. Jeśli potrzebowały jeszcze Jelcyna, to przede wszystkim w roli gwaranta utrzymania istniejącego status quo, nietykalności dokonanego rozdziału własności i bezpieczeństwa osobistego. System musiał mieć swojego lidera i dopiero pojawienie się realnej alternatywy - Władimira Putina zakończyło erę Jelcyna. Zbiegło się to z końcem drugiej kadencji prezydenta, dlatego też trudno powiedzieć

8 А.Б. Даугавет, Неформальные практики российской элиты (Апробация когнитивного подхода), „Роlis” 2003, $\mathrm{nr} 4$, s. 27.

9 Т. Грэхэм, Новый российский режим, „Независимая газета”, 23.11.1995.

10 D.E. Hoffman, The Oligarchs: Wealth and Power in the New Russia, New York 2002, s. 2.

11 А. Зудин, Кремль как субъект избирательной кампании, (w:) Россия в избирательном цикле 1999-2000 годов, ред. М. Макфол, Н. Петров, А. Рябов, Москва 2000, s. 99-100. 
czy zmiana na Kremlu była efektem kompromisu elit, zwycięstwa jednej z grup (służb bezpieczeństwa) czy efektem samodzielnej decyzji Jelcyna.

\section{Organizacja przestrzeni władzy w modelu Władimira Putina}

Ukształtowany za rządów Jelcyna system polityczny sankcjonował głęboką policentryczność i szeroką autonomię elit. Autonomia ta polegała na kwestionowaniu politycznej kontroli centrum nad korporacyjnymi „dominiami” (określone terytorium, firma, holding itp.). Umożliwiała szerokie i niekontrolowane korzystanie z zasobów państwa. Powodowała też głęboką dywersyfikację odpowiedzialności politycznej. Obecność w państwie silnej grupy oligarchów i regionalnych liderów posiadających własne zasoby polityczne była jedną z głównych przeszkód na drodze do przywrócenia monocentrycznego modelu władzy. Znalezienie skutecznej alternatywy dla sytemu wzajemnej zależności i gry interesów między politycznym centrum a regionami i biznesem stało się więc jednym z pierwszych celów nowej polityki Kremla.

Wylansowanie nowego lidera - Władimira Putina - spowodowało ostateczny upadek systemu Jelcyna, a także budowanego przez niego modelu stosunków politycznych opartych na układzie walczących ze sobą „,koterii”. Putin, jeśli chciał naprawdę rządzić, nie mógł być dłużej zakładnikiem „oligarchów”, nie mógł tolerować intryg, które od wewnątrz rozsadzały jego władzę. Musiał pozbyć się ,,szarych eminencji” czy „faworytów”, zbudować nową formułę władzy opartą na wertykalnej odpowiedzialności i państwowej biurokracji. W ten sposób reżim rozpoczął swoją ewolucję od modelu opartego na „drużynie prezydenta”, następnie „faworytyzmie”, „nepotyzmie" i "familii" do modelu militarystycznego-autorytaryzmu budowanego wokół „służb”. Nastąpił więc pozorny powrót do sytuacji z lat 1993-1996, kiedy to „siłownicy” odgrywali istotną rolę na Kremlu. W rzeczywistości nowy autorament odznaczał się dużo wyższymi przymiotami w dziedzinach organizacji władzy, inżynierii społecznej, socjotechnik itd. Nie był to więc powrót do brutalnej i prymitywnej siły Aleksandra Korżakowa, ale próba stworzenia nowych, inteligentnych, lojalnych i zdyscyplinowanych struktur władzy. Służby zaczęły stanowić podstawowe zaplecze analityczne i kadrowe. Wywodzi się z nich część członków aparatu władzy pełniących istotne funkcje, obdarzonych przy tym pełnym zaufaniem prezydenta. Można tu zauważyć drastyczną różnicę w porównaniu z czasami Jelcyna. Również poprzedni prezydent nie stronił od „,siłowników”, ale zasadniczy trzon jego ekipy budowali ludzie związani z gospodarką: Gajdar, Czubajs, Jasin, Bierezowski i im podobni. Teraz polityczne centrum wyraźnie przesunęło się w stronę struktur bezpieczeństwa, sięgając, zależnie od szczebla władzy.

Władimir Putin, poprzez zmiany form rządzenia, przystąpił do demontażu resztek „liberalnej” Rosji Jelcyna. Jelcynowskie „wyborcze samodzierżawie” zostało 
zastąpione „biurokratycznym autorytaryzmem”12. Trudno stwierdzić, czy owa konsekwencja wynikała ze ścisłej realizacji powziętego wcześniej planu, czy też była uwarunkowana splotem okoliczności determinujących taki, a nie inny rozwój wydarzeń $^{13}$. Bez względu na to należy stwierdzić, że od 2000 roku system polityczny Rosji uległ głębokim przeobrażeniom, polegającym na drastycznym umocnieniu władzy prezydenta.

Istotnymi aspektami przywracania systemu odpowiedzialności i kontroli w państwie była reintegracja systemu władzy. Jej główne elementy to: deautonomizacja elit, przezwyciężenie rozłamu w politycznym zapleczu Kremla i podporządkowanie prezydentowi ustawodawczych i wykonawczych instytucji państwa. Bardzo ważnym krokiem okazało się przejęcie kontroli nad Dumą, a tym samym nad procesem ustawodawczym. Putin działał racjonalnie i metodycznie. Od samego początku dał wszystkim siłom politycznym wyraźny sygnał, że jest tylko jeden - prezydencki ośrodek władzy. Nie pozwolił sobie na eksperymenty z niepokornymi premierami, przejawiającymi zbytnie ambicje polityczne oligarchami czy generałami, „niesfornymi” liderami Podmiotów Federacji. Naczelną zasadą tworzonego systemu stała się jego funkcjonalna stabilizacja, tj. wyciszenie mocą autorytetu i zdecydowaniem władzy wszelkich konfliktów. Putin dopuszczał, co prawda, szybkie i błyskotliwe kariery, sam kreował powstawanie nowej elity, jednak tylko na polu wyznaczonym przez Kreml, w orbicie jego wpływów. Naruszenie tego ładu szybko i nieuchronnie owocowało problemami z prokuraturą, a następnie pozbyciem się - czasem fizycznym - niepokornej jednostki. W tym kontekście ewolucja rosyjskiego autorytaryzmu polegała na doskonaleniu umiejętności budowania nowego i podporządkowywania sobie starego zaplecza. Stopniowe ograniczanie jego autonomii nieuchronnie wskazywało kierunek ewolucji władzy politycznej. Silna, autorytarna władza Putina sprzyjała stopniowej likwidacji jej alternatywnych ośrodków, a tym samym powodowała wyciszanie się konfliktów wewnątrz układu rządzącego. Rosja Putina stała się bardziej schematyczna i uporządkowana. Wszelkie przejawy emancypacji czy niesubordynacji elit zaczęły być duszone w zarodku. W okresie rządów Jelcyna, każda zmiana w okolicy szczytów lub zaplecza władzy wywoływała polityczną burzę. W systemie Putina zmiana stała się naturalną konsekwencją suwerennej decyzji prezydenta, który namaszczał swoim autorytetem, mógł też jednak pozbawić swego poparcia. Taka swoista „ekskomunika” była bardzo groźna, bowiem w Rosji tradycyjnie nie szereguje się ludzi według stanowisk czy rangi, ale według tego, jaki konkretnie wpływ są w stanie wywrzeć. Rosja Putina nie była, rzecz jasna, wolna od intryg politycznych, nie były one jednak tak chaotyczne, jak w czasach Jelcyna.

\footnotetext{
12 Л. Шевцова, Как Россия не справилась с демократией: логика политического отката, „Pro et Contra” 2004 , nr 3, t. 8, s. 36.

13 A. Małaszenko, D. Trenin piszą, że w 1999 roku Putin nie miał żadnego programu: А. Малашенко, Д. Тренин, Время Юга: Россия в Чечне, Чечня в России, Москва 2002, s. 56.
} 
Naturalną charakterystyką reżimu Putina stało się też doskonałe zrozumienie politycznej roli środków masowego przekazu. Media (zarówno stare jak i nowe) zaczęły być traktowane jako kluczowe narzędzie walki politycznej.

Chcąc skonsolidować swoją władzę w państwie, Putin musiał też odbudować koalicję rosyjskich elit, które wykazywałyby się całkowitą subordynacją i mogłyby stać się oparciem dla reżimu. Zrobiono to bardzo szybko i w zasadzie bez większych problemów. Ci, którzy nie chcieli zaakceptować nowej sytuacji, zostali zniszczeni. $\mathrm{Na}$ ich miejscu pojawili się przedstawiciele nowej elity. Dołączyli oni do starych „oligarchów”, którzy rozumieli i zaakceptowali nowe reguły gry. Putin w zasadzie odtworzył model władzy Jelcyna, tj. system oparty na konsensusie elit zarządzanych przez lidera/arbitra. Różnicę stanowiło to, że Putin był bardziej bezwzględny, nie był skrępowany mitem „demokraty”, nie tolerował „wichrzycielstwa”, nie pozwalał też, by konflikty wewnątrz establishmentu przenikały do społeczeństwa. Nieuchronne tarcia i przeciwności w łonie klasy rządzącej stały się tak trudne do obserwacji, jak konflikty wewnątrz elit ZSRR.

System Putina okazał się więc sprawniejszy od systemu Jelcyna, ale też bardziej zamknięty. Trudno powiedzieć na ile formuła władzy „putinizmu” ma charakter kolektywny, a na ile jest to monistyczna władza lidera. Wydaje się, że polityczne centrum nowej Rosji jest raczej tworem kolektywnym - swoistym „politbiurem” czy jelcynowską „familią”. Z pewnością Putin opiera się na swoich „oligarchach”, których siła i wpływy są nawet większe niż „oligarchów” Jelcyna. Można wskazać stałą grupę ludzi z otoczenia Kremla, która prawdopodobnie rządzi Rosją, a której Putin jest zapewne tylko liderem. W jej skład wchodzą: Dmitrij Miedwiediew, Igor Sieczyn, Siergiej Iwanow, Siergiej Czemiezow, Jurij Kowalczuk, Giennadij Timczenko, Arkadij i Boris Rotenberg. W tym gronie ścierają się „liberałowie” i „siłownicy”. Prezydent dba o to, aby nie dochodziło między nimi do głębszych kolizji interesów, ale także o to, aby jedna grupa nie zyskała stałej przewagi nad drugą. Można w tym dostrzec kolejną analogię $\mathrm{z}$ systemem lat 90 . Istotną różnicą jest $\mathrm{w}$ tym porównaniu umiejętność wypełniania swoich funkcji przez lidera układu. Jelcyn potrafił inicjować konflikty, potrafił poruszać się w skrajnie niesprzyjających warunkach, nie potrafił natomiast ich kontrolować. Jego działania powodowały ciągłe rozedrganie systemu i w konsekwencji - niepewność. Putin z kolei przyniósł elitom stabilizację, także poprzez jasne określenie hierarchii i mechanizmów władzy. „Oligarchowie” Putina są bardziej lojalni wobec lidera niż ich poprzednicy wobec Jelcyna. Pytanie tylko, czy owa lojalność wynika ze wspólnoty interesów, ze strachu czy może z obu tych kwestii na raz. Niewątpliwa większa sprawność systemu Putina wynika z z jego bezwzględności wobec przeciwników (cecha ta była Jelcynowi w zasadzie obca), ale przede wszystkim z umiejętności połączenia w jednym obozie wszystkich zantagonizowanych wcześniej sił. W Rosji Putina lider stał się autentycznym arbitrem, który umiejętnie powściąga, nieuchronne w łonie elit, tarcia. Kontroluje równowagę między wspierającymi reżim grupami. Nie pozwala, by ewentualne konflikty 
przedostały się do opinii publicznej. Władza - w oglądzie zewnętrznym - jest silna, zintegrowana i konsekwentna. Elity zostały zmuszone do pełnej lojalności wobec państwa, co jest tożsame z lojalnością wobec władzy,

Umocnienie monocentrycznego modelu władzy wymagało powszechnej i zgodnej akceptacji społecznej. Dokonano tego poprzez zabiegi socjotechniczne i manipulacyjne. Przede wszystkim przekonano opinię publiczną, że wszelkie działania prowadzone przez prezydenta są dobre dla Rosji i dla narodu. Zaczęto pokazywać Rosję jako kraj niekwestionowanego sukcesu ekonomicznego i politycznego. Korzystając z wysokich cen surowców (głównie ropy i gazu), zrównoważono budżet, co przedstawiano jako namacalny dowód sukcesu prezydenta. Miało to szczególny wydźwięk w kontekście pamięci o krachu finansowym z 1998 roku. Wreszcie, wykorzystując dobrą koniunkturę międzynarodową, umocniono pozycję Rosji w świecie, co również zostało pozytywnie odebrane przez obywateli.

\section{Podsumowanie}

Można zastanawiać się w jakim stopniu, czy i na ile, Rosja, z którą mamy do czynienia po 2000 roku jest wytworem działań i decyzji podejmowanych przez Borysa Jelcyna. W ogólnym zarysie oba systemy: Jelcyna i Putina - są tożsame: hierarchiczne, nepotyczne, oparte na dominacji lidera, który rządzi w oparciu i porozumieniu z gronem zaufanych ludzi. Dla obu polityków najważniejszym celem było utrzymanie i skonsolidowanie władzy. Reformy były traktowane jako sposób na zwiększenie wydolności struktur państwowych. Miało to skutkować zwiększeniem możliwości redystrybucji zasobów a w konsekwencji także poprawą wizerunku rządzących. Niewątpliwie system Putina jest rozwinięciem, a może nawet zwieńczeniem systemu stworzonego przez jego poprzednika - czymś, co Jelcyn chciał osiągnąć, ale z wielu względów było to niemożliwe. O porażce Jelcyna zadecydowały czynniki niezależne, takie jak załamanie gospodarcze lat 90. czy fatalna koniunktura na surowce energetyczne, ale też ogólnie większa skala problemów niż ta, przed którą stanął Putin. Z pewnością zaważyły tu również cechy charakteru obu prezydentów. Wielkim błędem Jelcyna - przy czym możliwe, że nie miał innego wyboru - było budowanie systemu władzy w oparciu o stały konflikt między „,starymi grupami interesu”, „liberałami” i „siłownikami”. Prezydent nie potrafił (lub nie chciał) utrzymać między nimi równowagi - jedna z nich zawsze osiągała okresową przewagę. Prowadziło to do cyklicznych rewolucji w centrum władzy, a w konsekwencji - do braku jednolitej linii reform. Co gorsza, odpychane grupy zasilały opozycję, której jedynym programem była walka z władzą, to zaś dodatkowo destabilizowało państwo.

Putin, który pozornie wydawał się politykiem bardziej ugodowym niż Jelcyn (choć też nie stroniącym od otwartej konfrontacji), w przeciwieństwie do swojego 
poprzednika, unikał bezpośredniego angażowania się w rozliczne konflikty. Frontalną walkę pozostawiał swoim współpracownikom, dzięki czemu mógł osiągnąć pozycję, do której Jelcyn stale dążył: politycznego arbitra i ostatecznej instancji ${ }^{14}$. Trudno wszakże nie zauważyć faktu, że Putin zerwał stare układy i kompromisy epoki Jelcyna, zawiązując nowe, ale już na zupełnie innych warunkach - absolutnie korzystnych dla swego otoczenia. W kolejnych latach przeobrażeniu uległa cała Rosja, a system dominacji lidera, którego to modelu podwaliny Jelcyn budował, osiągnął swoją pełnię. Zmieniła się hierarchia ważności poszczególnych instytucji państwa, pojawiły się nowe elity. Najważniejsze znaczenie miało tu jednak marginalizowanie konfliktu politycznego, co można uznać za końcowy etap przeobrażenia systemu politycznego. W Rosji Putina nastąpiła celowa, polityczna fragmentaryzacja społeczeństwa przy jednoczesnym pobudzeniu oczekiwanej przez reżim unifikacji jego reakcji na poczynania władzy. Społeczeństwo zostało odgrodzone murem od realnej polityki, której i tak nie było w stanie zrozumieć, bowiem jej istotą stała się sprawna manipulacja i zarządzanie przez lidera mikro-różnicami w łonie rządzącej elity. Przywódca został pośrednikiem między społeczeństwem a całą sferą skrywanych, tajnych, niejasnych, zakulisowych interesów, które naturalnie przynależały do sfery władzy. W konsekwencji, nastąpiła pogłębiająca się izolacja władzy i depolityzacja społeczeństwa, żyjącego swoim własnym życiem, problemami i potrzebami.

\section{BIBLIOGRAFIA}

Afanasjew J., Groźna Rosja, Oficyna Naukowa 2004.

Афанасьев М.Н., Клиентелизм и российская государственность, Москва 2000.

Ananicz A., Magdziak-Miszewska A., Sienkiewicz B., Rosja 1996 - przełom czy kontynuacja?, Warszawa 1997.

Aron, L., Yeltsin: A Revolutionary Life, New York: St. Martin's Press, 2000.

Åslund A., Jak budowano kapitalizm. Transformacja Europy Środkowej i Wschodniej, Rosji i Azji Środkowej, Warszawa 2010.

Ayer, Eleanor H, Boris Yeltsin: Man of the People, New York: Dillon Press, 1992.

Bäcker R., Rosyjskie myślenie polityczne za czasów prezydenta Putina, Wyd. Adam Marszałek, 2007.

Czajowski A., Demokratyzacja Rosji w latach 1987-1999, Wrocław 2001.

Durka B., Kryzys gospodarczy w Rosji. Geneza, skutki, scenariusze rozwoju sytuacji, Warszawa 1998. Jach A., Rosja 1991-1993. Walka o kształt ustrojowy państwa, Kraków 2011.

Klebnikov P., Ojciec chrzestny Kremla. Rosja w dobie gangsterskiego kapitalizmu, Warszawa 2010.

14 С. Фортескью zastanawiał się jednak, czy to nie sami oligarchowie postanowili wyznaczyć sobie arbitra. Por.: С. Фортескью, Правит ли россией олигархия?, „Polis” 2002, nr 5. 
Organizacja przestrzeni władzy przez Borysa Jelcyna i Władimira Putina...

Клямкин И., Шевцова Л., Внесистемный режим Бориса II: некоторые особенности политического развития постсоветской России, Моск. Центр Карнеги, Москва, Сигналъ, 1999.

Klyamkin I., Shevtsova L., This Omnipotent and Impotent Government: The Evolution of the Political System in Post-Communist Russia, Moscow 1999.

Marciniak W., Rozgrabione imperium. Upadek Związku Sowieckiego i powstanie Federacji Rosyjskiej, Kraków 2001.

McFaul M., Russia's Unfinished Revolution: Political Change from Gorbachev to Putin, Cornell University Press, 2001.

Медведев Р., Борис Ельцин. Народ и власть в конце XX века: Из наблюдений историка, Москва, «Время», 2011.

Rosefielde S., Russia in the 21st Century: The Prodigal Superpower, Cambridge University Press 2005.

Rosja w okresie prezydentury Władimira Putina, red. A. Stępień-Kuczyńska, S. Bieleń, Adam Marszałek Toruń 2008.

Skrzypek A., Druga smuta. Zarys dziejów Rosji 1985-2004, Warszawa 2004.

Shevtova L., Puins Russia, CarnegieEndowment for International Peace, Waszyngton 2003.

Шевцова Л., Посткоммунистическая Россия: логика развития и перспективы, Москва, Моск. Центр Карнеги, 1995.

Зудин А., Режим Владимира Путина: контуры новой политической системы, Москва, Моск. Центр Карнеги, 2002. 


\section{ORGANIZATION OF THE AREAS OF POWER BY BORIS YELTSIN AND VLADIMIR PUTIN - SIMILARITIES AND DIFFERENCES}

This analysis is an attempt to show how the "areas of political power" understood as a system of "game' mechanisms - functioned in the days of Boris Yeltsin and how it functions today under Vladimir Putin, taking into consideration the triangular interrelationships of the president, the ruling elite and interest groups. The article presents the similarities and difference between the two politicians and what factors influence Vladimir Putin's actions.

Keywords: President, Power, Russia, Yeltsin, Putin

Słowa kluczowe: Prezydent, władza, Rosja, Jelcyn, Putin 